\title{
Cikkismertetés: Okoznak az egészségegyenlőtlenségek biológiai elváltozásokat?
}

\author{
Article review: Do health inequalities cause biological embodiment?
}

\begin{tabular}{ll}
\hline Ismertető: & Vitrai József \\
Ismertetett cikk: & Vineis P., Delpierre C., Castagné R., Fiorito G., McCroy C., Kivimaki M., Stringhini S., \\
& Carmeli C. \& Kelly-Irving M. (2020). Health inequalities: Embodied evidence across \\
& biological layers. Social Science \& Medicine, 246:112781. doi: $\underline{10.1016 / j . s o c s c i-~}$ \\
& med.2019.112781 \\
Kulcsszavak: & egészségegyenlőtlenségek; biológiai elváltozás; kockázati tényezők \\
Keywords: & health inequalities; biological embodiment; risk factors
\end{tabular}

Beküldve: 2021. 06. 13., doi: 10.24365/ef.v62i3.6586

\section{HÁTTÉR}

A legfontosabb nem fertőző betegségek és kockázati tényezőik (például az elhízás, a magas vérnyomás, a cukorbetegség, a dohányzás, a mozgásszegény életmód, az egészségtelen táplálkozás és a túlzott alkoholfogyasztás) tekintetében a társadalmi-gazdasági egyenlőtlenségek jól dokumentáltak. Egy kulcsfontosságú kutatási kérdés azonban megválaszolatlan maradt: vajon létezik-e olyan, az emberi szervezetben kimutatható további biológiai elváltozás, ami az egészségegyenlőtlenségek hátterében álló társadalmi-gazdasági körülményektől és a már említett kockázati tényezőktől független? Mivel az élethosszig tartó társadalmi-gazdasági körülmények véletlenszerűen nem befolyásolhatók, az egyik út a bizonyítékok különböző biológiai szintjeinek vizsgálata, beleértve a molekuláris változásokat is.

\section{MÓDSZER}

Ebben a módszertani tanulmányban a szerzők beszámolnak a hátrányos társadalmi-gazdasági helyzet, valamint a) az egészség hosszú távú változásaival, a kockázati tényezők figyelembevételével és a nélkül; b) a betegségekre való fogékonyságot növelő biológiai közvetítő tényezőkkel, mint például a gyermekkori elhízással; c) a köztes, vérben kimutatható biomarkerekkel ${ }^{1}$ és omikai ${ }^{2}$ mérésekkel (transzkriptomika, DNSmetiláció, gyulladási fehérjék, allosztatikus terhelés ${ }^{3}$ ); és d) az immunitással való összefüggéseiről. A szerzők Lifepath konzorciumában ezeket az elemzéseket számos kohorszvizsgálatban - országban, kontextusban, valamint az életút különböző szakaszaiban - mintegy 1,7 millió alanyon végezték el. A fö cél azon feltételezés tesztelése volt, hogy az egyes biológiai szinteket (halál, funkcionális kimenetelek, DNS, RNS, fehérjék, fertőzések) különböző típusú torzítások és zavaró tényezők jellemzik, és hogy a különböző biológiai szinteken talált hasonló eredmények megerősítik az ok-okozati összefüggések értékelését.

\section{EREDMÉNYEK}

Az eredmények a társadalmi egyenlőtlenségek és a kedvezőtlen egészségi kimenetelek következetes összefüggéseit mutatják, amelyek a

\footnotetext{
1 A biomarkerek olyan vérből vagy vizeletből kinyert sejt- vagy molekuláris összetevők, amik az egészségi állapotnak vagy a szervezet működésének megfelelőségét jelzik. Szokásosan mért biomarker a koleszterin- vagy a vércukorszint.

${ }^{2}$ Az omika olyan tudományág, ami a szervezet vagy a sejtek struktúráját, funkcióját és a sejtek változásában szerepet játszó biomolekulák mennyiségi jellemzését végzi. Ilyenek pl. az öröklődést vizsgáló genomika, a fehérjék funkcióit vizsgáló proteomika.

${ }^{3}$ A hosszabb ideig fennálló testi-lelki terhelés, másképpen krónikus stressz hatására kialakuló biológiai elváltozások.
} 
gyulladásos biomarkerekre, a DNS- vagy RNSalapú markerekre, a fertőzésekre, a funkcionalitási mutatókra és a halálozásra terjednek ki. Bár az egyes összefüggések mindegyikéhez másmás zavaró tényezők tartoznak, a dózis-válasz kapcsolat mégis következetesen megfigyelhető, ami a többszintű megközelítés erejét mutatja.

\section{KÖVETKEZTETÉSEK}

Ez az új bizonyíték a társadalmi hátrány biológiai elváltozásokban történő megjelenését támasztja alá, a betegségek ismert, főként viselkedéses kockázati tényezőinek hatása mellett.

\section{TANULSÁGOK A HAZAI SZAKEMBEREK SZÁMÁRA}

Az ismertetett cikk felhívja a figyelmet arra, hogy a hátrányos társadalmi-gazdasági helyzet, akárcsak a krónikus stressz, biológiai elváltozások formájában "nyomot hagy" a szervezetben. Emiatt ezek az egyének fogékonyabbak és egyúttal kevésbé ellenállók lesznek a betegségekkel szemben. A fenti elváltozások részben a viselkedési kockázatok hatását közvetítik, részben azoktól függetlenek. Ezért az egészségegyenlőtlenségek elemzésekor nem elegendő a viselkedési kockázatokra történő korrigálás, a "rejtett" biológiai elváltozásokat biomarkerek elemzésbe történő bevonásával lehet kimutatni.

Másik fontos tanulság, hogy csupán a viselkedési kockázatok szűrésével az egészségi állapotról nem lehet megbízható információhoz jutni, mivel a korábbi, az egészségi állapotot rontó hatások okozta biológiai elváltozások csak a biomarker-vizsgálatokkal kimutathatók.

Információk a szerzőről:

Vitrai József, független népegészségügyi szakértő, vitrai.jozsef@gmail.com 